\title{
A szegénység és depriváció a magyar településállományban az ezredfordulót követően - avagy kísérlet a települési deprivációs index létrehozására
}

\author{
Poverty and deprivation in Hungarian settlements after the \\ Millennium - an attempt at creating a rural deprivation index
}

\author{
KOÓS BÁLINT
}

Koós Bálint: tudományos munkatárs, MTA Közgazdaság- és Regionális Tudományi Kutatóközpont, Regionális Kutatások Intézete, Budapest; koosb@rkk.hu

KULCSSZAVAK: Magyarország, szegénység, index, depriváció

ABSZTRAKT: A szegénységgel kapcsolatos kérdésekkel hagyományosan a szociológia foglalkozik, de a területfejlesztés, illetve tágabban a fejlesztéspolitika is érintett a kérdésben. A szegénység területi dimenziójának megragadása bár mindkét megközelítésben megjelenik, mégsem alkot koherens kutatási fókuszt. Jelen írás célja, hogy e hiányosság pótlására tegyen kísérletet és egyszerre érvényesítse ezt a két megközelítésmódot. A szegénység területi dimenziójának feltárásakor a szegénységet Townsend nyomán több dimenzióban megnyilvánuló erőforrás-, illetve lehetőséghiányként (depriváció) értelmezem, amely meggátolja a társadalomban elfogadott, megszokott életkörülmények elérését. A lakhatás, a képzettségi színvonal, a munkaerő-piaci részvétel, a jövedelmi viszonyok és a demográfiai jellemzők megragadására sztenderdizált mutatókat készítettem, amelyből főkomponens-analízis révén egyetlen deprivációs indexet képeztem. Ez a települési deprivációs index világosan kirajzolja az ország klasszikus fejlettségi térrendjét: a nagyvárosok és azok szűkebb-tágabb agglomerációi jelentik az ország kedvező helyzetű pólusait, amelyektől távolodva a több dimenzióban megtapasztalható hátrányos helyzet - szegénység - egyre meghatározóbbá válik. Összességében ez a települési deprivációs index nyilvánvaló hiányosságai ellenére a szakmai felhasználók számára alkalmas vonatkoztatási pontot jelenthet, amikor deprivációval, szegénységgel kapcsolatban kell forráselosztási döntéseket hozni, vagy éppen valamilyen társadalmi jelenség vizsgálatához keresnek alkalmas társadalmi háttérváltozót.

Bálint KOós: research fellow, Institute for Regional Studies, Centre for Economic and Regional Studies, Hungarian Academy of Sciences, Budapest; koosb@rkk.hu

KEYWORDS: Hungary, deprivation, index, poverty

ABSTRACT: Poverty research has a centuries-old tradition and has become a multi-coloured research field both by the research tools applied and its methodology. Traditionally, sociology addresses issues concerning poverty; however, keeping these research interests within one discipline would be a misleading approach, since territorial development and development policies (Lowe et al. 1986) must also deal with poverty issues: demarcation of developed and

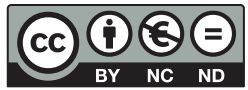


developing territories and relevant development policies necessarily aim at reducing and eliminating poverty.

Although addressing the territorial aspect of poverty has been challenged in both approaches, it has not formed a coherent research focus. The aim of this paper is to make an attempt to fill this gap and justify these two approaches. According to Peter Towsend $(1979,31$.$) ,$ poverty is defined as a multi-dimensional shortage of resources and opportunities that, for instance, hinders maintaining socially accepted life circumstances and limits participation in education or employment. This kind of deprivation is usually addressed at individual-family level; however, it has highly significant spatial aspects, too. Actual geographical space is not homogeneous because it does not provide equal opportunities to meet people's needs that led some Anglo-Saxon scholars in the '80s to suggest that urban and rural areas have a distinct nature of deprivation. In line with that, the selection of variables is a deliberate process, because inappropriate variables would lead to revealing urban and rural differences instead of identifying multidimensional poverty. Therefore, aspects of housing, qualification, labour market participation, income conditions and demographics have been considered in the study as well.

These variables have been standardised ("Z-score") with the rural average and the deviation calculated from the sample and defined for three years (1990, 2001, 2011). Afterwards, a principal component analysis has been carried out in order to see if the standardised variables can be converted into a comprehensive deprivation indicator. In order to define the indicator with the same set of variables for a multiple-year result, both the time range was narrowed down (2001, 2011) and the number of variables was reduced, too. High values of the deprivation indicator suggest that people live even under the rural average according to certain poverty dimensions (housing, income, labour market opportunities and qualification). In other words, the higher the value of the indicator is, the lower the average social status is. The deprivation indicator can clearly illustrate the usual spatial structure of the country: Large towns and their narrow and broad agglomerations can be identified as the prosperous poles of the country, while with increasing distance, more and more factors show significant levels of poverty.

Analysing the factors affecting the deprivation indicator using a linear regression estimating function results in the finding that the greater the population of a settlement is and the closer located to a county capital, the lower the value of the deprivation indicator is. If a certain settlement is a subregion capital or part of suburbia, the deprivation indicator shows some improvement.

To sum up, the deprivation indicator, even with its obvious imperfections, can be an effective tool in case of decision making on resource distribution to address poverty issues. Furthermore, it can also be used as a background variable when investigating social phenomena.

\section{Bevezetés}

A szegénység kutatása évszázados múltra tekint vissza, a kutatási terület napjainkra rendkívül sokszínűvé vált mind kérdésfeltevésében, mind kutatási eszközeiben, mind módszertanában. Hagyományosan a szegénységgel kapcsolatos kérdésekkel a szociológia foglalkozik, de hiba lenne a kutatási terület egyetlen diszciplínához kötése, hiszen például a területfejlesztés, a fejlesztéspolitika (Lowe, Bradley, Wright 1986) is érintett a kérdésben: a fejlett-fejletlen területek lehatárolása, s erre irányuló fejlesztéspolitika kialakítása természetszerűen a szegénység mérséklését, felszámolását célozza.

A két (szociológiai, illetve fejlesztéspolitikai) megközelítés a saját célrendszerét követi, s bár a szegénység területi dimenziójának megragadását mind- 
kettő érinti, de nem ez a vizsgálatok központi kérdése. A hazai szegénységvizsgálatok (így például Gábos, Szivós 2009; Spéder 2002; a Tárki Monitor Jelentései, illetve Társadalmi Riport sorozata) döntően a jövedelmi szegények demográfiai, családi, lakhatási, foglalkoztatási körülményeinek és a fö struktúráknak a feltárására törekednek, s bár a lakóhely településtípusának jelentőségére rámutatnak, figyelmen kívül hagyják a jelenség hátterében meghúzódó területi egyenlőtlenségeket (Szoboszlai 2004). Sajátos módon a roma problematikával foglalkozó szociológusok körében - így például Virág Tünde (2006, 2010), Havas Gábor (1999), Ladányi János (Ladányi, Szelényi 1997) műveiben - nagy hangsúlyt kap a területi dimenzió, de ők az etnikus szegénységet helyezik a vizsgálataik középpontjába.

A másik oldalról a fejlesztéspolitikai irányultságú vizsgálatok ugyan területi fókuszúak, de nem csupán a szegénységet vizsgálják, hiszen egyéb fejlesztési célokra is figyelemmel kell lenniük, így például az infrastrukturális ellátottságra vagy éppen a kutatás-fejlesztési kapacitásokra, amelyek azonban nem szorosan kapcsolódnak a szegénység problematikájához. Jelen írás célja, hogy egyszerre érvényesítse a kétfajta megközelítésmód szempontrendszerét, s így hozzájáruljon a szegénységkutatások területi dimenzióval történő bővítéséhez.

E cél érdekében először áttekintem mind a szociológiai, mind pedig a fejlesztéspolitikai megközelítés főbb vonásait a szegénység területi dimenziójának feltárása szempontjából, majd pedig kísérletet teszek egy területi deprivációs index kialakítására.

A szegénység szociológiai vizsgálata során a Higgs-White szerzőpáros (Higgs, White 2000, 8-9.) négy fö megközelítési módot különböztet meg, amely számomra is kiindulópontot jelent: egyrészt a hagyományosnak mondható egyetlen, jövedelmi dimenzióban értelmezett szegénységfelfogást (poverty), másrészt a több dimenzióban értelmezett hátrányt (depriváció), harmadrészt a több dimenzióban időbeli folyamatként megélt társadalmi kirekesztést (exclusion), negyedrészt a kérdést egyenlőtlenségként megragadó irányzatot.

Ezen elméleti megközelítések a szegénység térbeli vizsgálatára nem egyformán alkalmasak, ha figyelembe vesszük a rendelkezésre álló statisztikai adatok jellemzőit. A szegénységmegközelítések ugyanis alapvetően egyéni vagy háztartási szinten értelmezhetőek, erre vonatkozó teljes körü adatfelvételek azonban a legritkább esetben állnak rendelkezésre. A területi dimenzió figyelembevételekor így szükségszerűen másodlagos statisztikai adatforrásokat kell igénybe venni. A személyi jövedelemadó hazai bevezetése (1988) óta rendelkezésre állnak erről a településsoros adatok, ám a szegénység területi dimenzióinak vizsgálatakor az egydimenziós, jövedelmi szegénység megközelítése ellen két érv is megfogalmazható. Egyrészt az adóelkerülés mértékében is komoly területi differenciáltság figyelhető meg, másrészt a jól-rosszul megragadott jövedelem „vásárlóértéke” sem független a helytől. Bublik Bence és Tóth István János 2013-as kistérségi szintű kutatása arra a megállapításra jutott, hogy a be nem jelentett jövedelmek nagysága, aránya erős területi differenciáltságot mutat, s éppen az ország gazdasá- 
gilag fejletlenebb kistérségeiben jellemző az országos átlagot jóval meghaladó adózatlan jövedelemszerzés (Bublik, Tóth 2013). A jövedelmi adatokon alapuló szegénységi megközelítés másik komoly problémája, hogy ugyanazon jövedelem eltérő fogyasztási szintet tesz lehetővé a tér különböző pontjain. Egyrészt a szolgáltatások mennyiségi és minőségi jellemzői területileg differenciáltak, másrészt a fogyasztáshoz eltérő utazási többletköltségek kapcsolódnak. Ezt a problémát a Központi Statisztikai Hivatal is érzékeli, a Létminimum, 2013 című KSH-kiadvány rá is mutat arra, hogy a létminimum-számítás módszertanának megújítására van szükség, mert a jelenlegi csupán országos szinten alkalmazható. Bár feltételezhető lényeges regionális és településcsoportonkénti differenciáltság, ezek feltárására az alkalmazott módszer és minta nem alkalmas (KSH 2014, 1.). Hazai vizsgálatok hiányában itt csupán utalni lehet a releváns angliai kutatás eredményeire (Smith, Davis, Hirsch 2010), amely szerint az országosan meghatározott létminimum eléréséhez a vidéken élők számára eltérő mértékủ többletjövedelem szükséges. Ez a többletjövedelem-igény településtípusonként és háztartástípusonként differenciált (1. táblázat), egy vidéki városban élő kétgyermekes házaspár esetében például az országos szinthez képest 12\%-kal magasabb költséget jelent a létminimumba sorolt fogyasztói kosár elemeinek megszerzése. A vidéki háztartásokat sújtó többletköltségek döntő része, 60-100 százaléka a megnövekedett közlekedési igényeknek tudható be.

A jövedelmi szegénység megragadásakor tehát kettős - s ráadásul ellentétes előjelű - torzító hatás érvényesül, hiszen a vidéki térségekben egyrészt a költségszínvonal, másrészt pedig a tényleges jövedelem is magasabb az adatok alapján vártnál, ami összességében korlátozza, korlátozhatja a kapott eredmények megbízhatóságát. Nem maga a jövedelmi egyenlőtlenség ténye $\mathrm{s}$ iránya - sokkal inkább a mértéke kérdőjelezhető meg.

Az egydimenziós jövedelmi szegénység koncepciója után tekintsük át vázlatosan a többdimenziós szegénységfelfogásokat! A depriváció - azaz, ahogy Peter Townsend (1979) a fogalmat eredetileg bevezette: az objektív relatív depriváció - arra utal, hogy az adott egyén, társadalmi csoport nem rendelkezik elegendő erőforrással ahhoz, hogy a társadalomban elfogadott, szokásos életfeltételeket biztosítsa maga számára, s az ennek megfelelő életmódot folytassa. A

1. táblázat: Településtípus és háztartástípus szerint differenciált létminimum Angliában (százalékpontos eltérés az országos értékhez képest) Absolute poverty line according settlement and household types in England (deviation from the country average in percentage points)

\begin{tabular}{lccc}
\hline \multicolumn{1}{c}{ Háztartástípus } & Vidéki város & Község & Kisközség \\
\hline Nyugdíjas házaspár & $1 \%$ & $19 \%$ & $22 \%$ \\
Egyedülálló felnőtt & $9 \%$ & $18 \%$ & $24 \%$ \\
Aktív korú házaspár két gyermekkel & $12 \%$ & $15 \%$ & $18 \%$ \\
Egyedülálló felnőtt egy gyermekkel & $9 \%$ & $14 \%$ & $16 \%$ \\
\hline
\end{tabular}

Forrás: Smith, Davis, Hirsch 2010. 
depriváció többdimenziós szegénységmegközelítésnek tekinthető, hiszen figyelembe veszi az oktatási, munkaerő-piaci, lakhatási, jövedelmi dimenziókat is. Amennyiben a szükséges erőforrások és feltételek nem állnak rendelkezésre, a deprivált csoport tagjai képtelenek az adott társadalomban elfogadott (s esetenként elvárt) életmódot folytatni, nem képesek bekapcsolódni a különböző társadalmi tevékenységekbe. A deprivált csoport tagjai ezzel ténylegesen kirekesztődnek olyan fontos alrendszerekből, mint az oktatás vagy éppen a munkavállalás.

Ez a kirekesztődés már át is vezet a következő megközelítéshez, a társadalmi kirekesztés - illetve kirekesztődés (social exclusion) - fogalmához, amely a szegénységproblematika időbeliségére és többdimenziós voltára irányítja rá a figyelmet. A fogalom alapvetően egyéni, családi szinten értelmezhető. Ugyan vizsgálható területi dimenzióban is, de - mivel célzott, időben ismétlődő panelfelvételeket igényel - erőforrásigénye miatt országosan nem alkalmazható a szegénység területi dimenziójának megragadására.

Mindezek alapján a szegénység területi dimenzióban történő vizsgálatára a deprivációs megközelítés javasolható, amely szorosan kapcsolódik a fejlesztéspolitikához, a települési és térségi fejlettségvizsgálatokhoz.

A tértudományok hazai képviselői az utóbbi évtizedekben nagyszámú publikációban foglalkoztak a magyar településállomány fejlettségi szempontú vizsgálatával, tipizálásával. E munkák a hatvanas években még inkább a településosztályozás céljával készültek (lásd bővebben Beluszky 1965, 1969, 1973), azaz a települések funkcionális szerepének, tagolódásának feltárására, illetőleg a városok hierarchikus szintjeinek, vonzáskörzeteinek meghatározására születtek. A hatvanas évek második felétől megerősödtek a településfejlettségi kutatások, sorra születtek ezzel kapcsolatos publikációk (lásd például Bene 1967; Kiss 1969). A települési fejlettség vizsgálata természetesen vezetett a hátrányos helyzetü térségek kutatásához, amely a hetvenes években már nagyszámú publikációban öltött testet (lásd például Barta, Beluszky, Berényi 1975; Erdélyi 1968; Lackó 1975). A rendszerváltást követő években a válságtérségek lehatárolása került előtérbe (így például Rechnitzer 1993; Tatai 1992), majd a konszolidációval ismét a települési és térségi fejlettségi vizsgálatok kerültek fókuszba (többek közt Faluvégi 2000; Molnár, Skultéty 2002). Ezek a kutatások jellemzően a fejlesztéspolitikához kapcsolódtak, valamely közpolitikai beavatkozás (területfejlesztés) megalapozása, vagy éppen értékelése, kritikája volt a publikáció célja. Aligha meglepő, hogy ezek a vizsgálatok alapvetően a településhálózat valamilyen dimenzióiban - fejlettség, versenyképesség, innovációs potenciál (Bajmócy 2012), foglalkoztatás (Kovács, Bihari 2007) - értelmezett pólusait kívánták változatos módszerek alkalmazásával megragadni, hogy ezzel a figyelmet s a fejlesztési forrásokat az adott szempontból rászoruló, fejlesztendő települések, térségek felé tereljék.

A fejlesztendő települések szisztematikus lehatárolásának igénye a közpolitika formálói körében is felmerült, ami oda vezetett, hogy az elmaradott települések lehatárolásáról rendelkezett a 2015/1986. (XI. 5.) minisztertanácsi 
határozat. A lehatárolás során figyelembe vett tényezők, folyamatok meglepő stabilitást mutatnak a következő évtizedekben, ha megvizsgáljuk a területfejlesztési szempontból releváns lehatárolásokat:

- 2015/1986. (XI. 5.) minisztertanácsi határozat az elmaradott települések lehatárolásáról;

- 84/1993. (XI. 11.) országgyűlési határozat a területfejlesztési támogatás irányelveiről és a kedvezményezett területek besorolásának feltételrendszeréről;

- 97/1997. (XI. 6.) országgyűlési határozat a területfejlesztési támogatások és a decentralizáció elveiről, a kedvezményezett területek besorolásának feltételrendszeréről szóló 30/1997. (IV. 18.) országgyűlési határozat módosításáról;

- 24/2001. (IV. 20.) országgyülési határozat a területfejlesztési támogatások és a decentralizáció elveiről, a kedvezményezett térségek besorolásának feltételrendszeréről;

- 67/2007. (VI. 28.) országgyülési határozat a területfejlesztési támogatásokról és a decentralizáció elveiről, a kedvezményezett térségek besorolásának feltételrendszeréről.

Bár a lehatárolás alapját képező dimenziók időben változékonyságot mutatnak - egyes területek kiesnek, illetőleg újabb területek mutatói kerülnek be, de összességében a hazai lehatárolások vázát alkotó társadalmi-gazdaságiinfrastrukturális mutatók körében nagyfokú állandóság figyelhető meg (2. táb-

2. táblázat: A hazai területfejlesztési politika által a területi fejlettség és fejletlenség megragadására alkalmazott dimenziók, 1986-2007

Dimensions of territorial development and underdevelopment applied by Hungarian territorial development policy regimes between 1986 and 2007

\begin{tabular}{|c|c|c|c|c|c|}
\hline Dimenziók & 1986 & 1993 & 1997 & 2001 & 2007 \\
\hline Demográfia & $\mathrm{x}$ & $\mathrm{x}$ & $\mathrm{x}$ & $\mathrm{x}$ & $\mathrm{x}$ \\
\hline Iskolázottság & & $\mathrm{x}$ & $\mathrm{x}$ & & $\mathrm{x}$ \\
\hline Munkanélküliség & (x) & $\mathrm{x}$ & $\mathrm{x}$ & $\mathrm{x}$ & $\mathrm{x}$ \\
\hline Szociális helyzet & & & & & $\mathrm{x}$ \\
\hline Jövedelmi szint & $\mathrm{x}$ & $\mathrm{x}$ & $\mathrm{x}$ & $\mathrm{x}$ & $\mathrm{x}$ \\
\hline Infrastruktúra & $\mathrm{x}$ & $\mathrm{x}$ & $\mathrm{x}$ & $\mathrm{x}$ & $\mathrm{x}$ \\
\hline Lakásmutatók & $\mathrm{x}$ & $\mathrm{x}$ & $\mathrm{x}$ & $\mathrm{x}$ & $\mathrm{x}$ \\
\hline Közlekedés, elérhetőség & $\mathrm{x}$ & & & $\mathrm{x}$ & $\mathrm{x}$ \\
\hline Urbánus, rurális jelleg & (x) & & $\mathrm{x}$ & & $\mathrm{x}$ \\
\hline Kutatók, fejlesztők száma & & & & $\mathrm{x}$ & $\mathrm{x}$ \\
\hline Mezőgazdasági adottságok & $\mathrm{x}$ & $\mathrm{x}$ & & & \\
\hline Gazdasági szervezetek száma & & & $\mathrm{x}$ & $\mathrm{x}$ & $\mathrm{x}$ \\
\hline Foglalkoztatási szerkezet & $\mathrm{x}$ & $\mathrm{x}$ & $\mathrm{x}$ & & \\
\hline Turizmus & & & $\mathrm{x}$ & $\mathrm{x}$ & $\mathrm{x}$ \\
\hline
\end{tabular}

Forrás: saját szerkesztés Nagy 2012, 55. alapján. 
lázat). A jövedelemi szinttel, munkanélküliséggel, demográfiai jellemzőkkel, infrastrukturális ellátottsággal, lakáshelyzettel kapcsolatos változók valamennyi lehatárolásban szerepet játszottak - még ha nem is feltétlenül azonos változók révén. Fontos rámutatni arra, hogy a hazai lehatárolás mutatói/dimenziói közül több rendkívül pontosan illeszkedik a többdimenziós szegénység statikus leképezését jelentő deprivációs megközelítéshez - így különösen az iskolázottság, a jövedelem, a munkanélküliség és a lakáskörülmények tekintetében figyelhető meg egybecsengés.

A területfejlesztési célú lehatárolásokban a fent jelzett deprivációs dimenziók mellett megjelennek olyan változócsokrok is, amelyek a fejlesztéspolitika egyéb - például gazdaságfejlesztési - céljainak megvalósításához kapcsolódnak és szorosan nem kötődnek a szegénységproblematikához (pl. kutatás-fejlesztésben dolgozók száma, foglalkoztatási szerkezet, gazdasági szervezetek száma és sűrűsége vagy éppen a különböző infrastrukturális mutatók). Témánk szempontjából tehát a területfejlesztést megalapozó mutatórendszer túl bő, olyan területeket is számításba vesz, amelyek a szegénység területi dimenziója szempontjából relevanciával nem bírnak.

\section{Kísérlet a hazai deprivációs index kialakítására}

A szociológiai és fejlesztéspolitikai megközelítési módok vázlatos áttekintése után kíséreljük meg a kétfajta szempontrendszer együttes érvényesítését! A szegénység területi dimenziójának feltárásakor a szegénységet Peter Townsend $(1979,31$. nyomán több dimenzióban megnyilvánuló erőforrás- és lehetőséghiányként értelmezzük, amely meggátolja a társadalomban elfogadott, megszokott életkörülmények elérését, korlátozza a részvételt olyan fontos területeken, mint az oktatás vagy éppen a munkavállalás. Ezt a több dimenzióban értelmezett megfosztottságot tekintjük deprivációnak, amely ugyan alapvetően egyéni vagy családi szinten értelmezhető, mégis rendkívül komoly területi összetevői vannak.

A valós földrajzi tér ugyanis e tekintetben sem homogén, nem biztosít azonos lehetőségeket az igények kielégítésére - ami alapján angolszász kutatók (így például Mark Shucksmith, Tom Bradley) már az 1980-as években felvetették az urbánus és a rurális terek eltérő deprivációs természetét (Higgs, White 2000). Erre tekintettel nagyon körültekintően kell meghatározni a változók körét, hiszen alkalmatlan változókkal nem a többdimenziós szegénységet, hanem az urbánus-rurális dimenzió eltéréseit ragadhatjuk meg. A lakhatási deprivációról például teljesen eltérő eredmény adódik, ha a lakás méretét vagy a lakás komfortfokozatát vesszük górcső alá, hiszen Magyarországon a vidéki lakások jellemzően nagyobb alapterületűek, ám kevésbé komfortosak. Ebből a megfontolásból a deprivációs indexbe a komfort nélküli lakott lakások arányát érdemes bevonni, hiszen az a város-vidék dichotómiától függetlenül képes megragadni a 
társadalom által elvárt lakásminőségtől való eltérést. Az oktatási lehetőségekhez való hozzáférésben, az iskolázottsági szintben a diplomások aránya vagy az átlagos elvégzett iskolai osztályok száma markáns települési lejtőt mutat, a várostérségek, nagyvárosi agglomerációk egyértelmű előnyével. Ilyen megfontolásból a választóvonalat nem a diplománál, hanem alacsonyabb oktatási szintnél érdemes meghúzni, azt vizsgálva, hogy a népesség mekkora része rendelkezik legalább középfokú iskolai végzettséggel. A munkaerő-piaci deprivációról a szokásosnak mondható munkanélküliségi rátát, a jövedelmi deprivációról pedig az egy állandó lakosra jutó átlagos adózott jövedelmet emeltem be a vizsgálatba. Mind a nemzetközi, mind pedig a hazai vizsgálatok arra mutatnak, hogy a munkanélküliség egyéni szinten is komoly szegénységi tényező, ám ha a munkajövedelem hiánya az egész háztartást sújtja, a hatás még drámaibb, ezért a munkanélküliségi rátán túl az olyan foglalkoztatott nélküli háztartások arányát is figyelembe vettem, ahol csupán munkanélküli volt (tehát nem számoltam a foglalkoztatott nélküli inaktív és eltartott háztartásokkal). Tekintettel arra, hogy a hazai kutatások (így például Tóth 2013) egyöntetűen arra mutatnak rá, hogy a gyerekszám fontos szegénységi tényezo, az indexbe egy kormegoszlást jelző változót is beépítettem (60 éven felüliekre jutó 0-14 évesek száma).

E változók értékeit három időpontra $(1990,2001,2011)$ is meghatároztam, a változókat sztenderdizáltam a Budapest nélkül számított lélekszámmal súlyozott települési átlaggal, illetve a mintából számított szórással. Tekintettel arra, hogy egyes mutatók (pl. munkanélküliség, foglalkoztatott nélküli háztartások, komfort nélküli lakások aránya) esetében a magas érték, míg más esetekben - például jövedelmi mutató vagy éppen a legalább középfokú iskolai végzettségüek aránya - az alacsony érték jelzi a deprivációt, ezért szükséges a mutatók értékeinek egyirányúsítása. Ezt az érintett változók sztenderdizált értékeinek előjelváltásával tehetjük meg, így biztosítva, hogy minden változó esetében a negatív értékek a vidéki átlagnál kedvezőbb, míg a pozitív értékek az átlagnál kedvezőtlenebb helyzetre utaljanak. Amennyiben az adott változó nulla értéket vesz fel, az azt jelzi, hogy az adott település az adott dimenzióban éppen a vidéki átlagnak megfelel.

A sztenderdizált változókon fókomponens-analízist végeztem el, hogy megvizsgálhassam, az érintett változók összevonhatók-e egyetlen mutatóba, a deprivációs indexbe, s ehhez milyen súlyozást szükséges alkalmazni. A főkomponens-analízissel meghatározhatóvá vált az egyes időpontokban a változók kommunalitása, amely alapján láthatóvá vált, hogy amennyiben azonos változói körrel szeretnénk az index értékét meghatározni, szükséges a változók körét és a vizsgált időszakot leszűkíteni (3. táblázat). A később oly meghatározó munkanélküliség ugyanis 1990-ben még nem volt széles körü társadalmi probléma, a foglalkoztatottak nélküli háztartások számáról nem is közölt adatot a Központi Statisztikai Hivatal. Ahogyan az a 3. táblázatból is látható, 2001-ben a korstruktúrát jelző mutatót annak alacsony kommunalitása miatt (nem érte el a küszöbnek tekintett 0,25-ös értéket) még ki kellett hagyni. Ez alapján azt 
3. táblázat: Kommunalitásértékek a deprivációs indexhez felhasznált változók körében

$(1990,2001,2011)$

Communalities for variables used in constructing the deprivation index $(1990,2001,2011)$

\begin{tabular}{lrrr}
\hline \multicolumn{1}{c}{ Változó } & 1990 & 2001 & 2011 \\
\hline 100 fö 60 év felettire jutó 15 év alatti lakos & 0,230 & 0,106 & 0,259 \\
Csak munkanélküli taggal bíró, foglalkoztatott nélküli háztartások aránya & - & 0,671 & 0,669 \\
Munkanélküliek a gazdaságilag aktív népesség arányában & 0,212 & 0,778 & 0,762 \\
Legalább középfokú iskolai végzettségűek a 25-X éves népesség arányában & 0,824 & 0,481 & 0,707 \\
Átlagos adózott jövedelem havonta egy állandó lakosra & 0,789 & 0,743 & 0,724 \\
Komfort nélküli lakások aránya & 0,795 & 0,629 & 0,631 \\
\hline
\end{tabular}

Megjegyzés: Szürke háttér jelöli a deprivációs indexet alkotó változókat. 1990-re a KSH nem közölte a foglalkoztatott nélküli háztartások számát, arra az időpontra csupán 5 változóval készült a fókomponensanalízis.

mondhatjuk, hogy két időpontra - a 2001. és 2011. évre - a deprivációs index értékei 5 változóval meghatározhatóak. Ahogyan a táblázatból is látható, a deprivációs indexben két változó - a csak munkanélküli háztartástaggal bíró foglalkoztatott nélküli háztartások aránya, illetve a munkanélküliek a gazdaságilag aktív népesség arányában - is a munkanélküliséggel kapcsolatos. Ez egyben azt is jelenti, hogy a deprivációs indexben nagyobb hangsúlyt kap a munkaerö-piaci depriváció, mint a lakhatási, a jövedelmi vagy a képzettségi depriváció. Ennek hátterében az a megfontolás áll, hogy a szegénységi tényezők közt kiemelkedő jelentősége van a munkaerő-piaci státusznak, a munkavállalás lehetőségétől tartósan megfosztottak ugyanis idővel a többi dimenzióban is hátrányos helyzetbe kerülnek.

Az ily módon kiszámított deprivációs index értékei települési szinten ragadják meg az ott élők szegénységi helyzetét. Az index magas értékei arra utalnak, hogy az ott élők jellemzően több szegénységi dimenzióban (lakhatás, jövedelem, munkaerő-piaci lehetőségek, képzettség) is a főváros nélkül számított települési átlagnál kedvezőtlenebb pozícióban vannak. Az index értéke minél magasabb, annál kedvezőtlenebb - azaz a „vidéki” átlagtól annál inkább elmarad - az ott élők átlagos helyzete. Nagyon fontos rámutatni arra, hogy a települési szintű deprivációs index csupán a jellemző, ,átlagos lakosokról” szolgáltat információt, az átlag pedig a településen belüli heterogenitást elrejti. Egy magas deprivációs indexű településen éppen úgy élhetnek kedvező helyzetű lakosok, mint ahogyan a legjobb helyzetü településen is élnek több dimenzióban is hátrányos helyzetűnek mondható lakosok. A települési szintű mutatók legnagyobb problémája éppen az, hogy a nagyobb lélekszámú településeken a nagyobb fokú heterogenitás miatt a depriváció nem ragadható meg, mert a jó, illetve jobb helyzetü társadalmi csoportok mutatói feljavítják a képet.

A számítás menetéből adódóan a deprivációs index a település adott időpontbeli relatív helyzetét - azaz a főváros nélkül számított magyar települési átlaghoz mért pozícióját - jelzi. Ebből adódóan a különböző időpontokra ki- 
számított deprivációs indexek közvetlenül nem összevethetőek, az elmozdulás megragadására az értékek valamilyen sorba rendezése (pl. rangszámmá alakítás, decilisekbe vagy kvintilisekbe sorolás) szükséges. A 4. táblázatban látható a tipizálás eredménye: ebben az esetben a településeket a deprivációs index értékei alapján tíz, egyenlő elemszámú osztályba soroltam, mind 2001-ben, mind pedig 2011-ben. A legkedvezőbb helyzetű települések kerültek az 1. osztályba, a legkedvezőtlenebbek pedig a 10.-be. Az egyes településosztályokra meghatározva a főbb deprivációs területek mutatóit láthatóvá vált egy markáns deprivációs lejtő. A táblázat adataiból érdemes rámutatni arra, hogy a legjobb és legrosszabb helyzetű településosztályok között a munkanélküliségi rátában több mint ötszörös (!) volt a különbség 2001-ben, ekkor a legrosszabb helyzetben lévő települések lakott lakásainak közel fele $(43,6 \%)$ még komfort nélküli volt s a 25 évesnél idősebb népesség kétharmadának csak alapfokú végzettsége volt. Hozzá kell tenni, hogy egyetlen évtized alatt is komoly mértékủ javulást tükröznek a népszámlálási adatok: minden településosztályban - a legrosszabb helyzetűnél is! - megfigyelhető a képzettségi színvonal emelkedése és a komfort nélküli lakások arányának mérséklődése. A lakhatásban a legjelentősebb pozitív irányú változás éppen a legkedvezőtlenebb helyzetű települések körében (10. településosztály) tapasztalható, ahol is a komfort nélküli lakott lakások aránya 43-ról 28 százalékra csökkent. A munkanélküliségben egy sajátosságra kell rámutatni: miközben a 2008-as világgazdasági válság kirobbanását követően az ország egészében nőtt a munkanélküliség, az állami beavatkozás révén megvalósult közmunka-

4. táblázat: A deprivációs index értékei alapján képzett településosztályok fontosabb mutatói, 2001, 2011

Socio-economic characteristics of settlement categories constructed by the deprivation index, 2001, 2011

\begin{tabular}{ccccccc}
\hline $\begin{array}{c}\text { Település- } \\
\text { osztály }\end{array}$ & $\begin{array}{c}\text { Legalább középfokú iskolai } \\
\text { végzettséggel bírók a } 25-X \\
\text { éves népesség arányában }\end{array}$ & \multicolumn{2}{c}{$\begin{array}{c}\text { Munkanélküliek a } \\
\text { gazdaságilag aktívak } \\
\text { arányában }\end{array}$} & \multicolumn{2}{c}{$\begin{array}{c}\text { Komfort nélküli lakások } \\
\text { aránya }\end{array}$} \\
\cline { 2 - 7 } & 2001 & 2011 & 2001 & 2011 & 2001 & 2011 \\
\hline 1. & 79,3 & 88,0 & 7,1 & 9,9 & 4,1 & 1,9 \\
2. & 71,1 & 81,0 & 9,9 & 11,8 & 9,1 & 3,6 \\
3. & 64,1 & 75,8 & 10,0 & 12,2 & 12,6 & 6,4 \\
4. & 60,0 & 71,2 & 11,6 & 14,0 & 16,8 & 8,3 \\
5. & 57,3 & 68,4 & 13,7 & 15,2 & 18,7 & 10,1 \\
6. & 52,3 & 65,0 & 15,0 & 16,4 & 22,0 & 12,3 \\
7. & 50,3 & 62,0 & 17,8 & 18,2 & 27,2 & 15,5 \\
8. & 47,8 & 58,5 & 22,8 & 20,5 & 28,8 & 18,0 \\
9. & 44,3 & 53,7 & 28,5 & 24,7 & 33,1 & 21,2 \\
10. & 36,7 & 43,6 & 40,5 & 35,7 & 43,6 & 28,3 \\
\hline Magyarország & 66,8 & 76,8 & 11,1 & 13,1 & 13,0 & 6,9 \\
\hline
\end{tabular}


programok a deprivált térségekben a válság előtti - rendkívül magas szint alá vitték a munkanélküliségi ráta értékét.

Az index rövid bemutatása után vizsgáljuk meg, hogy a számítások eredményeként kapott index értékek mit mutatnak a szegénység területi dimenziójáról! A települési szintre számított deprivációs index értékei alapján készített kartogramok (1. és 2. ábra) a hazai regionalisták, valamint a területfejlesztésben dolgozók számára jól ismert képet tükrözik. A deprivációs index világosan kirajzolja az ország klasszikus fejlettségi térrendjét: a nagyvárosok és azok szükebb-tágabb agglomerációi jelentik az ország kedvező helyzetű pólusait, amelyektől távolodva a több dimenzióban megtapasztalható hátrányos helyzet - szegénység - egyre meghatározóbbá válik.

Ezt az agglomerációs területi sémát a kedvező közlekedési helyzet (autópálya, országos foútvonal, vasúti fơvonal melletti elhelyezkedés), illetve a kedvező földrajzi elhelyezkedés (Bécs-Budapest-Székesfehérvár-Zalaegerszeg által határolt térség) képes módosítani. Az agglomerációs jelenség hangsúlyozása talán furcsa lehet, de a vizsgálat során készített lineáris regressziós becslőfüggvény alapján a deprivációs index értékére szignifikáns és kedvező irányú hatással van a település lakónépessége, a KSH által lehatárolt agglomerációhoz, illetve agglomerálódó térséghez tartozás, valamint a megyei jogú város közúti

1. ábra: Települési depriváció a vidéki Magyarországon, 2001

(A deprivációs index értékei alapján képzett településötödök)

Settlement deprivation in rural Hungary, 2001 (quintiles of the deprivation index)

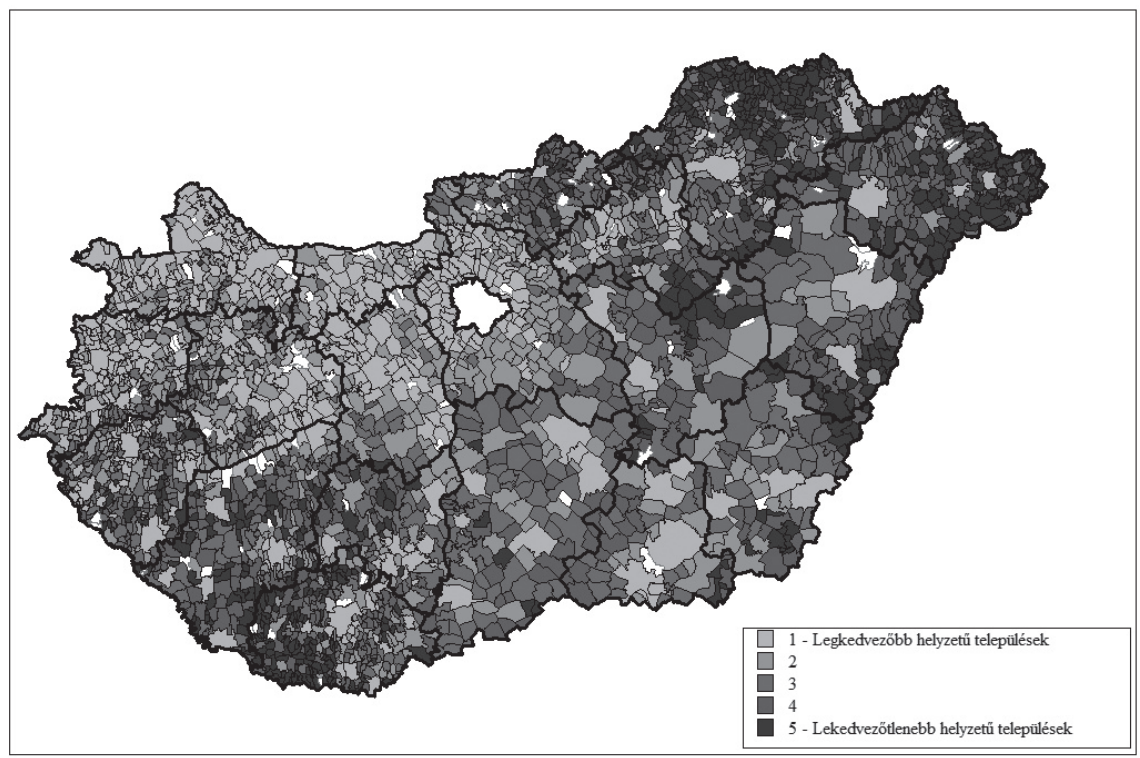

Megjegyzés: az ábrán a deprivációs index értékei nem jelennek meg azon települések esetében, amelyek 1990-ben még nem voltak önállóak. 
elérhetősége. Kisebb, de még szignifikáns jelentősége volt a települések közigazgatási szerepének (járásközponti, megyei jogú városi rang). A becslőfüggvény alapján tehát minél nagyobb a település lélekszáma, s minél közelebb van az egy megyei jogú városhoz, annál kedvezőbb lesz a deprivációs index értéke - amit kisebb mértékben tovább javít, ha az adott település egy agglomeráció részét képezi, illetve járásközponti szerepet is betölt.

A deprivált, azaz több dimenzióban is hátrányos helyzetű, szegény települések ezzel szemben erőteljes területi koncentrációt mutatnak, amelyek esetében egyrészt visszaköszönnek az ország tradicionálisan hátrányos helyzetűnek tekintett térségei: a Dráva mente, a Közép-Tisza-vidék, a román határsáv települései, Somogy és Baranya, valamint Nógrád, Borsod-Abaúj-Zemplén és Szabolcs-Szatmár-Bereg megye jelentős része, másrészt viszont megjelennek új problématerületek is. Érzékelhető Veszprém megye periferikus megyehatár menti térségeiben a több dimenzióban megnyilvánuló hátrányos helyzet, ahogyan Zala és Vas megye határán is kirajzolódnak problémás területek. Itt még nem lehet Dráva menti vagy éppen Cserehát szintű társadalmi problémákról beszélni, de látni kell, hogy az ország fejlettként elkönyvelt térségeiben is feltűnnek deprivált települések, településcsoportok.

Az ezredfordulót követő évtized a szegénység területiségében nem hozott komoly átrendeződést, a markáns pólusok változatlanok maradtak (2. ábra).

2. ábra: Települési depriváció a vidéki Magyarországon, 2011

(A deprivációs index értékei alapján képzett településötödök)

Settlement deprivation in rural Hungary, 2011 (quintiles of the deprivation index)

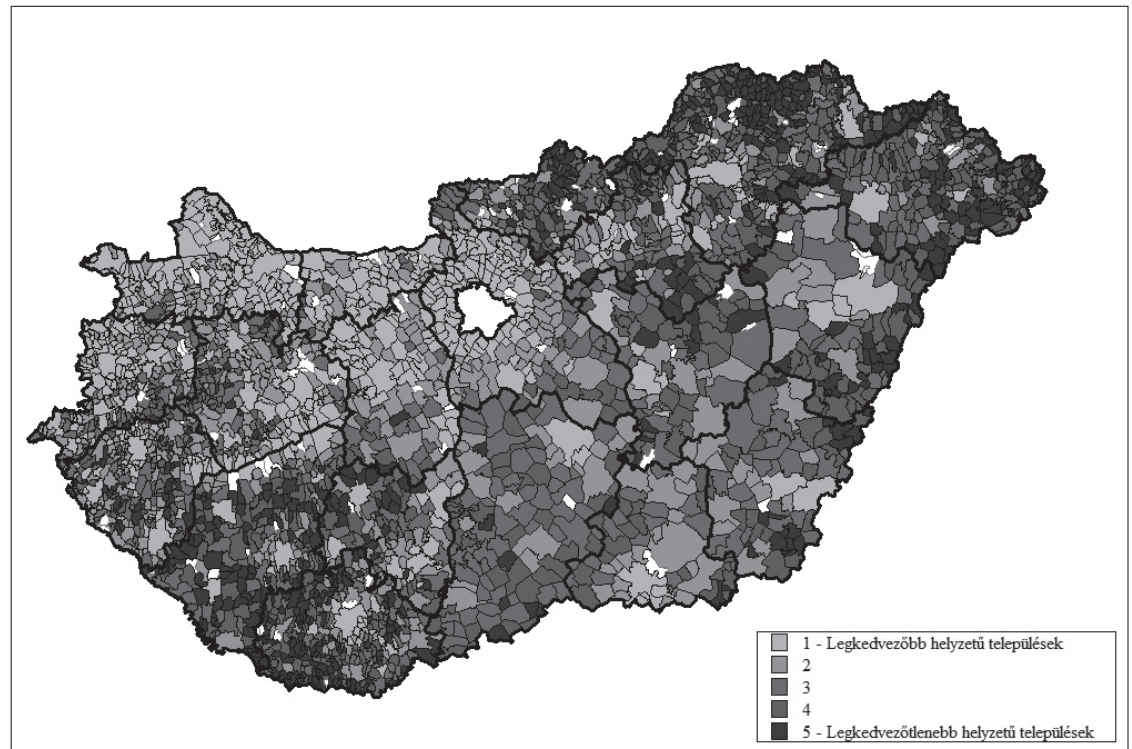

Megjegyzés: az ábrán a deprivációs index értékei nem jelennek meg azon települések esetében, amelyek 1990-ben még nem voltak önállóak. 
Megyei szinten vizsgálva a depriváltnak mondható településeken élők lélekszámát pontosabb képet kaphatunk a probléma intenzitásáról (5. táblázat) és a változás tendenciáiról. Szabolcs-Szatmár-Bereg megye kedvezőtlen helyzete aligha lep meg bárkit is, ám az már figyelemre méltó, hogy a megye lakosságának több mint négytizede szegény - deprivált - településen élt 2001-ben. Ez a mutató az ország klasszikusan hátrányos helyzetű megyéiben egyöntetűen magas értékeket vett fel az ezredforduló időszakában: Borsod-Abaúj-Zemplén megyében 34,9\%, Nógrádban 27,6\%. Az ellenkező póluson Pest, Győr-Moson-Sopron, Komárom-Esztergom megyék helyezkedtek el, ahol a népesség legalább nyolctizede élt a legkedvezőbb deprivációs helyzetű településeken.

A települések deprivációs helyzete nem állandó, a demográfiai folyamatok, a gazdaság változó térbelisége egy évtized alatt is jelentős átalakulást hozhat. Bács-Kiskun, Nógrád, Heves megye esetében például a deprivált településeken élők száma 3-5 százalékponttal nőtt, ami egyértelműen kedvezőtlen társadalmi-gazdasági folyamatokra hívja fel a figyelmet. Különösen fontos rámutatni a Nógrád megyében megfigyelhető drámai romlásra, hiszen a megye népességé-

5. táblázat: A deprivációs szempontból kedvező és kedvezőtlen helyzetű településeken élők aránya megyei bontásban $(\%, 2001,2011)$

People living in favourable and unfavourable settlements according to the deprivation index (by counties, \%, 2001, 2011)

\begin{tabular}{lcccc}
\hline \multirow{2}{*}{ Megye } & \multicolumn{2}{c}{$1-3$. településosztály } & \multicolumn{2}{c}{7 -10. településosztály } \\
\cline { 2 - 5 } & 2001 & 2011 & 2001 & 2011 \\
\hline Bács-Kiskun & 47,2 & 43,7 & 8,7 & 13,9 \\
Baranya & 71,4 & 61,3 & 14,0 & 14,2 \\
Békés & 40,7 & 42,6 & 17,5 & 17,9 \\
Borsod-Abaúj-Zemplén & 44,8 & 47,7 & 34,9 & 34,8 \\
Csongrád & 62,4 & 70,7 & 8,4 & 8,5 \\
Fejér & 82,4 & 73,9 & 1,3 & 2,8 \\
Győr-Moson-Sopron & 97,7 & 97,9 & 0,2 & 0,3 \\
Hajdú-Bihar & 48,0 & 52,5 & 24,1 & 19,8 \\
Heves & 56,8 & 59,6 & 15,1 & 20,8 \\
Jász-Nagykun-Szolnok & 31,3 & 33,0 & 24,3 & 21,7 \\
Komárom-Esztergom & 96,9 & 96,6 & 0,0 & 0,2 \\
Nógrád & 45,5 & 24,4 & 27,6 & 31,1 \\
Pest & 83,4 & 84,3 & 1,8 & 2,3 \\
Somogy & 55,9 & 50,5 & 21,3 & 23,8 \\
Szabolcs-Szatmár-Bereg & 31,4 & 32,5 & 46,5 & 40,6 \\
Tolna & 58,5 & 60,8 & 10,8 & 12,3 \\
Vas & 90,0 & 88,9 & 1,3 & 1,9 \\
Veszprém & 88,0 & 80,1 & 2,2 & 3,2 \\
Zala & 69,2 & 72,1 & 9,5 & 6,1 \\
\hline Budapest nélküli vidéki Magyarország & 62,7 & 62,8 & 14,8 & 14,5 \\
\hline & & & &
\end{tabular}


nek harmada (31,1\%) élt 2011-ben deprivált településen - ami már alig marad el a Borsod-Abaúj-Zemplén megyei szinttől $(34,8 \%)$. Heves megye déli részében szintén negatív folyamatok tapasztalhatóak, ami azért is különös, mert közlekedési szempontból nem tekinthető kedvezőtlen helyzetűnek a térség. BácsKiskun megye Csongrádhoz hasonlóan az ezredforduló tájékán még az Alföld kedvező helyzetű térségéhez volt sorolható, ahol a népesség alig 8-9 százaléka élt depriváltnak mondható településen, ám 2011-re jelentős számú település - így például Jánoshalma, Tiszaalpár, Bátya, Uszod, Mélykút, Gara - csúszott a deprivált kategóriába. Az ezredfordulót követő évtizedben Bács-Kiskun megye több települése is negatív társadalmi-gazdasági folyamatokkal szembesült, amelyek eredményeként deprivációs szempontból kedvezőtlenebb helyzetbe kerültek, mint Szabolcs-Szatmár-Bereg megye feltörekvő települései: Panyola, Ujjehértó, Máriapócs, amelyek 2001-ben még egyértelműen a kedvezőtlen helyzetű települések közé sorolódtak.

A területi depriváció vizsgálata során nem lehet megkerülni az etnicitás kérdését, hiszen a több dimenzióban is hátrányosnak mondható településeken a magukat romának vallók aránya jóval meghaladja az országos szintet. Ahogyan az a 3. ábrán is látható, markáns tendencia rajzolódik ki a település deprivációs szintje és a roma etnikumúak aránya között. A magukat romának vallók közel fele (47,5\%) él deprivált településen (7-10. településosztály), ahol korlátozottak a képzési lehetőségek, a munkanélküliség pedig rendkívül magas.

3. ábra: A magukat romának vallók aránya a deprivációs index alapján képzett

településosztályok szerinti bontásban (\%, 2011)

Proportion of self-identified Roma population in settlement types constructed by the deprivation index $(\%, 2011)$

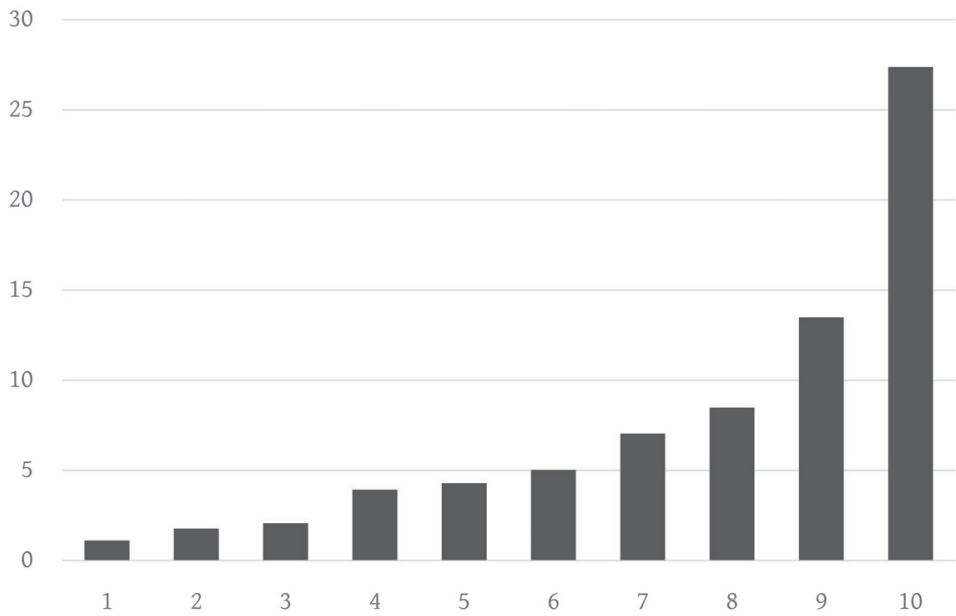




\section{Záró gondolatok}

A szegénység területi dimenziójának megragadása, az idő- és térbeli tendenciák feltárása a regionális kutatások egyik fontos területe, de fontos szerepet játszik a fejlesztéspolitika, a szociálpolitika formálásában is. A fentiekben bemutatott deprivációs index alkalmas vonatkoztatási pontot jelenthet a szakmai felhasználók számára, amikor deprivációval, szegénységgel kapcsolatban kell forráselosztási döntéseket hozni, vagy éppen valamilyen társadalmi jelenség vizsgálatához keresnek komplex szociológiai háttérváltozót. (Ennek megkönnyítésére a deprivációs index értékeit elérhetővé tesszük az intézet honlapján.)

Az etnicitás és a depriváció összekapcsolására már mutattunk példát, de érdekes kutatási iránynak látszik a hasonló jellemzőkkel bíró, ámde eltérő történelmi háttérrel bíró települések - például nemesi falu, cselédfalu, majorsági zsellérfalu, tanyás település, mezőváros stb. - közötti eltérések feltárása. A deprivációs index támpontot jelent az adott település több dimenzióban mért szegénységi helyzetéről - de egyetlen szám nyilvánvalóan nem nyújthat átfogó képet például a gyermekszegénységről, az energiaszegénységről, az otthon nélküliek problémáiról. A másik fontos hiányossága a deprivációs indexnek, hogy települési átlagértéket használ, az átlag pedig elfedi a településen belüli heterogenitást, ami fóként a nagyobb lélekszámú települések esetében jelent problémát. Ennek megoldását jelentheti, ha a vizsgálódást valamilyen alacsonyabb területi szintre, például népszámlálási számlálókörzet szintjére lehetne levinni.

\section{Irodalom}

Bajmócy Z. (2012): Innovációs index kistérségi szinten. Csak játék a számokkal? In: Bajmócy Z., Lengyel I., Málovics Gy. (szerk.): Regionális innovációs képesség, versenyképesség és fenntarthatóság. JATEPress, Szeged, 13-32.

Barta Gy., Beluszky P., Berényi I. (1975): A hátrányos helyzetű területek vizsgálata Borsod-AbaújZemplén megyében. Földrajzi Értesitö, 3., 299-388.

Beluszky P. (1965): Falusi településeink osztályozása. Földrajzi Értesitő, 1., 149-163.

Beluszky P. (1969): A települések osztályozásának néhány elvi-módszertani kérdése. Területi Statisztika, 6., 601-619.

Beluszky P. (1973): A településosztályozás néhány elvi-módszertani szempontja. Földrajzi Értesítő, 4., 453-466.

Bene L. (1967): Szempontok a települések fejlettségének és típusainak vizsgálatához. Demográfia, 1., 17-34.

Bublik B., Tóth I. J. (2013): Rejtett lakossági jövedelmek kistérségi szintü becslése. MKIK Gazdaság- és Vállalkozáskutató Intézet, Budapest

Erdélyi E. (1968): Baranya megye községeinek fejlettségi vizsgálata komplex mutató segítségével. Területi Statisztika, 2., 138-148.

Faluvégi A. (2000): A magyar kistérségek fejlettségi különbségei. Területi Statisztika, 4., 319-346.

Gábos A., Szivós P. (2010): Jövedelmi szegénység és anyagi depriváció Magyarországon. In: Kolosi T., Tóth I. Gy. (szerk.): Társadalmi Riport 2010. TÁRKI, Budapest, 58-82. 
Havas G. (1999): A kistelepülések és a romák. In: Glatz F. (szerk.): A cigányok Magyarországon. MTA, Budapest, 163-204.

Higgs, G., White, S. (2000): Alternatives to census-based indicators of social disadvantage in rural communities. Progress in Planning, 1., 1-81. http://doi.org/fnj34d

Kiss J. (1969): A településfejlettség mérésének és összehasonlításának egyes kérdései. Statisztikai Szemle, 6., 598-619.

Kovács K., Bihari Zs. (2006): Lejtők és csúszdák, avagy a foglalkoztatási esélyek térbeli egyenlőtlensége az ezredfordulón. Tér és Társadalom, 4., 49-66.

KSH (2014): Létminimum, 2013. Statisztikai Tükör, 2014/53.

Lackó L. (1975): Magyarország elmaradott területei. Földrajzi Értesitő, 3., 243-269.

Ladányi J., Szelényi I. (1997): Szuburbanizáció és gettósodás. Kritika, 7., 4-12.

Lowe, P., Bradley, T., Wright, S. (1986): Deprivation and welfare in rural areas. GeoBooks, Norwich

Molnár L., Skultéty L. (2002): A települési szintű relatív fejlettség meghatározása. Közgazdasági Szemle, 1., $74-90$.

Nagy A. (2012): A fejlettség, elmaradottság mérése a magyar területfejlesztési politikában. Doktori értékezés. ELTE TTK Földtudományi Doktori Iskola, Budapest

Rechnitzer J. (1993): Szétszakadás vagy felzárkózás. A térszerkezetet alakító innovációk. MTA RKK, Győr

Smith, N., Davis, A., Hirsch, D. (2010): A minimum income standard for rural households. Commission for Rural Communities, Joseph Rowntree Foundation, York

Spéder Zs. (2002): A szegénység változó arcai. Tények és értelmezések. Andorka Rudolf Társadalomtudományi Társaság, Századvég Kiadó, Budapest

Szoboszlai Zs. (2004): Szegénység, marginalizáció, szegregáció. Adalék a társadalmi egyenlőtlenségek értelmezéséhez. Tér és Társadalom, 3., 25-42.

Tatai Z. (1992): A válságterületek típusai és kezelésük Magyarországon. Földrajzi Közlemények. 3-4., 205-208.

Tóth I. Gy. (2013): Jövedelemeloszlás 2009-2012 között. In: Szivós P., Tóth I. Gy. (szerk.): Egyenlötlenség és polarizálódás a magyar társadalomban. TÁRKI Monitor Jelentés 2012. TÁRKI, Budapest, 9-36.

Townsend, P. (1979): Poverty in the United Kingdom: a survey of household resources and standards of living. Penguin Books, Harmondsworth

Virág T. (2006): The regional ghetto. Review of Sociology, 1., 51-70. http://doi.org/ckzh5j

Virág T. (2010): Kirekesztve. Falusi gettók az ország peremén. Akadémiai Kiadó, Budapest 